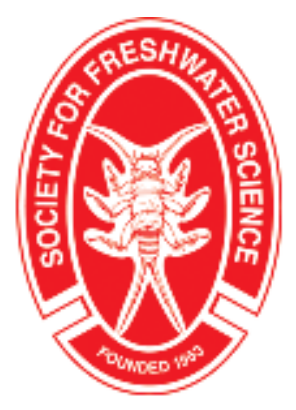

Phosphorus retention in a lowland Neotropical stream following an eight-year enrichment experiment

Author(s): Gaston E. Small, Marcelo Ardón, John H. Duff, Alan P. Jackman, Alonso Ramírez, Frank J. Triska and Catherine M. Pringle

Source: Freshwater Science, eshwater Science (March 2016), p. 000

Published by: University of Chicago Press on behalf of Society for Freshwater Science

Stable URL: http://www.jstor.org/stable/10.1086/684491

Accessed: 14-01-2016 18:11 UTC

Your use of the JSTOR archive indicates your acceptance of the Terms \& Conditions of Use, available at http://www.jstor.org/page/ info/about/policies/terms.jsp

JSTOR is a not-for-profit service that helps scholars, researchers, and students discover, use, and build upon a wide range of content in a trusted digital archive. We use information technology and tools to increase productivity and facilitate new forms of scholarship. For more information about JSTOR, please contact support@jstor.org. 


\title{
Phosphorus retention in a lowland Neotropical stream following an eight-year enrichment experiment
}

\author{
Gaston E. Small ${ }^{1,6}$, Marcelo Ardón ${ }^{2,7}$, John H. Duffe, ${ }^{3,}$, Alan P. Jackman ${ }^{3}$, Alonso Ramírez ${ }^{4,9}$, \\ Frank J. Triska ${ }^{3}$, and Catherine M. Pringle ${ }^{5,10}$ \\ ${ }^{1}$ Department of Biology, University of St Thomas, St Paul, Minnesota 55105 USA \\ ${ }^{2}$ Department of Biology, East Carolina University, Greenville, North Carolina 27858 USA \\ ${ }^{3}$ Water Resources Division, US Geological Survey, Menlo Park, California 94025 USA \\ ${ }^{4}$ Institute for Tropical Ecosystem Studies, University of Puerto Rico, San Juan, Puerto Rico 00931 USA \\ ${ }^{5}$ Odum School of Ecology, University of Georgia, Athens, Georgia 30602 USA
}

\begin{abstract}
Human alteration of the global P cycle has led to widespread P loading in freshwater ecosystems. Much research has been devoted to the capacity of wetlands and lakes to serve as long-term sinks for P inputs from the watershed, but we know much less about the potential of headwater streams to serve in this role. We assessed storage and retention of P in biotic and abiotic compartments after an 8-y experimental $\mathrm{P}$ addition to a $1^{\text {st }}$-order stream in a Neotropical wet forest. Sediment $\mathrm{P}$ extractions indicated that nearly all $\mathrm{P}$ storage was in the form of Fe- and Al-bound P ( $\sim 700 \mu \mathrm{g} \mathrm{P/g}$ dry sediment), similar to nearby naturally high-P streams. At the end of the enrichment, $\sim 25 \%$ of the total $\mathrm{P}$ added over the 8 -y study was still present in sediments within $200 \mathrm{~m}$ of the injection site, consistent with water-column measurements showing sustained levels of high net $\mathrm{P}$ uptake throughout the experiment. Sediment P declined to baseline levels $(\sim 100 \mu \mathrm{g} \mathrm{P} / \mathrm{g}$ dry sediment) over $4 \mathrm{y}$ after the enrichment ended. Leaf-litter P content increased nearly $2 \times$ over background levels during P enrichment and was associated with a $3 \times$ increase in microbial respiration rates, although these biotic responses were low compared to nearby naturally high$\mathrm{P}$ streams. Biotic storage accounted for $<0.03 \%$ of retention of the added P. Our results suggest that the high sorption capacity of these sediments dampened the biotic effects of P loading and altered the timing and quantity of P exported downstream.

Key words: phosphorus, sediments, sorption, storage, stream, tropical
\end{abstract}

Humans mobilize $>18$ million metric tons of $\mathrm{P}$ each year. This mobilization has led to a $75 \%$ increase in $\mathrm{P}$ stored in freshwater ecosystems compared to pre-industrial conditions (Bennett et al. 2001). P is commonly a limiting nutrient in freshwater ecosystems (Schindler 1977, Elser et al. 2007), but anthropogenic P loading can cause eutrophication in lakes and reservoirs (Carpenter and Bennett 2011). Even in heterotrophic headwater streams, P loading can affect resource availability and alter the structure of the food web (Peterson et al. 1985, Benstead et al. 2009, Davis et al. 2010).

We understand some of the potential ecological consequences of increased $\mathrm{P}$ availability in stream ecosystems (Slavik et al. 2004), but the relationship between P loading and ecological effects is complex because it depends on the capacity for $\mathrm{P}$ retention through biotic and abiotic mechanisms. Biotic uptake of P by algal cells or heterotrophic microbes depends on a number of factors including the availability of light (in the case of autotrophs) and additional nutrients, and available substrate for algal and microbial growth (Aldridge et al. 2010, Schade et al. 2011,
Drake et al. 2012). Some fraction of this P enters slowerturnover consumer biomass compartments (e.g., insects and fish; Small et al. 2009), and the ultimate fate of this consumer biomass could have important consequences for the ecosystem P budget (Vanni et al. 2013).

Abiotic P uptake occurs through sorption, which includes both adsorption to the surfaces of cationic minerals and precipitation with electrolytes (Froelich 1988, Reddy et al. 1999, House and Denison 2000). Sorption of P begins with a rapid ligand exchange reaction that takes place with the reactive surface groups, followed by a slow reaction with exchangeable cations in crystal lattices (Frossard et al. 1995). Sorption capacity increases with particle surface area and with positive surface charge, which depend on both mineralogy and $\mathrm{pH}$ of the solution (Chen et al. 1973). Sorption is an equilibrium reaction between $P$ in solid and solution phase, so higher levels of P loading result in net uptake by sediments and decreased P loading leads to net $P$ release from sediments.

The relative importance of biotic and abiotic mechanisms in P retention can vary depending on stream condi-

E-mail addresses: ${ }^{6}$ gaston.small@stthomas.edu; ${ }^{7}$ ardonsayaom@ecu.edu; ${ }^{8}$ jhduff@usgs.gov; ${ }^{9}$ aramirez@ramirezlab.net; ${ }^{10}$ cpringle@uga.edu 
tions and on P loading rates. At low levels of P loading, biotic uptake exceeds sorption (Elwood et al. 1981, Newbold et al. 1983), but under elevated P inputs, sorption becomes a dominant retention mechanism (Meyer 1979), buffering downstream P concentrations. Physical characteristics affecting interactions between water and substrate (e.g., stream depth, width, velocity, extent of hyporheic zone, presence of debris dams and other channel complexities) probably influence both biotic and abiotic P uptake and retention (e.g., House et al. 1995, Mulholland et al. 1997). Higher rates of biological P retention have been reported in headwater streams, where potential for biological exchange with water is greatest (Bukavekas 2007). The capacity for sediments to buffer concentrations of dissolved $\mathrm{P}$ in streams also is high in small streams where sediment surface area to water volume is greatest and contact time with sediments is relatively long (House and Denison 1998, 2002). However, other investigators have found that abiotic $P$ retention increases in importance downstream, where dissolved P levels are higher (Aldridge et al. 2010).

The time required to achieve equilibrium in response to point-source P loading may be much faster in stream ecosystems than in lakes, wetlands, or floodplains (Sharpley et al. 2014), but could still take months or years for several reasons. First, abiotic retention of P occurs as a 2-step kinetic process, with adsorption of $\mathrm{P}$ to the particle surface occurring on the order of minutes to hours and diffusion to the interior of the particle occurring on the order of days to months (Froelich 1988). Second, the downstream transport of fine particulates, under low-flow conditions (Jarvie et al. 2006) or from high-flow events (Dorioz et al. 1989, Drake et al. 2012), could move sediment-bound P downstream and expose new sediment for P sorption. New sediment entering the affected reach from above a point source or from lateral inputs creates new sinks for dissolved $\mathrm{P}$, potentially extending nonequilibrium conditions and dampening biotic effects downstream. In spite of these variables, most studies of $\mathrm{P}$ retention in streams rely on short-term experimental $\mathrm{P}$ additions (several hours to several days) to quantify biotic P uptake and are based on the implicit assumption that abiotic equilibrium is achieved rapidly (Stream Solute Workshop 1990). The few long-term experimental $\mathrm{P}$ additions (or $\mathrm{N}+\mathrm{P}$ additions) to streams ( $\mathrm{Pe}-$ terson et al. 1985, Slavik et al. 2004, Benstead et al. 2009) were focused on biotic responses rather than on quantifying the capacity of both biotic and abiotic processes to retain nutrients over time. Studies of $\mathrm{P}$ dynamics downstream of wastewater inputs have shown that retention of $\mathrm{P}$ by sediments plays an important role in buffering stream P levels under variable loading conditions (Haggard et al. 2005, Jarvie et al. 2006). However, we have less understanding of the contribution of biotic P storage and of the effect of abiotic P storage on biotic responses to long-term P loading.

In much of the tropics, where wastewater treatment is limited, populations are rapidly urbanizing, and agriculture is intensifying, the ability of streams to buffer the ef- fects of P loading could have important implications for maintaining biodiversity and supporting intact stream ecosystems. Here, we present the results and implications of an 8-y experimental $\mathrm{P}$ addition to a headwater stream in a tropical wet forest and examine the subsequent recovery of the stream following the cessation of $\mathrm{P}$ addition. We use patterns of spatial and temporal variation in $\mathrm{P}$ storage to assess the hypothesis that high $\mathrm{P}$ retention by sediments dampens biotic effects of point-source P loading.

\section{METHODS}

\section{Study site and description of previous research}

We conducted an 8-y experimental $\mathrm{P}$ enrichment in a $1^{\text {st }}$-order stream, the Carapa, at La Selva Biological Station, Costa Rica (lat $10^{\circ} 26^{\prime} \mathrm{N}$, long $84^{\circ} 01^{\prime} \mathrm{W}$ ). The stream drains dense secondary forest. Allochthonous leaf-litter input is high (Small et al. 2013), and light availability is low because of the dense multistratal canopy (Pringle et al. 1990). Stream discharge ranges from 2 to $3 \mathrm{~L} / \mathrm{s}$, and $\mathrm{pH}$ ranges from 5.0 to 5.5 (Small et al. 2012). Strongly weathered residual soils, originating from andesitic lava flows, are characteristic of small watersheds at La Selva including the Carapa. These soils were originally classified as ultisols (Sollins et al. 1994) but have been reclassified as oxisols (Kleber et al. 2007), which are common at tropical latitudes.

From 28 August 1998 to 17 February 2006, phosphoric acid $\left(\mathrm{H}_{3} \mathrm{PO}_{4}\right)$ was continuously released from a streamside, gravity-fed carboy. Because of the small size of the stream and a series of riffles below the injection site, complete mixing occurred within $10 \mathrm{~m}$ of the release site. Natural background soluble reactive P (SRP) levels for the Carapa are low $($ mean $=6.5 \mu \mathrm{g} / \mathrm{L})$. The target $\mathrm{P}$ concentration for the study reach during the experiment was $300 \mu \mathrm{g} / \mathrm{L}$, but the actual concentration decreased longitudinally and was highly variable over time because of variable rates of input and dilution, so the input acted as a dynamic point source. Over $8 \mathrm{y}$, a total of $53.8 \mathrm{~kg} \mathrm{P}$ was added to the stream (described by Small et al. 2008). During the enrichment period, stream $\mathrm{pH}$ averaged $5.32 \pm 0.52($ mean \pm SD) $10 \mathrm{~m}$ below the injection site, within the range of spatial and temporal variability observed in other small streams at La Selva during this period (Small et al. 2012).

Throughout the 8-y P addition, dissolved P measurements were conducted twice weekly at stations 10,50 , and $100 \mathrm{~m}$ downstream from the injection site. From these measurements, net uptake of dissolved P was calculated for 685 different days throughout the 2731-d experiment (Small et al. 2008). An analysis of these data indicate that patterns of net $\mathrm{P}$ uptake were consistent with sorption kinetics and that a high net $\mathrm{P}$-uptake rate was maintained over $8 \mathrm{y}$, but evidence of gradual saturation was found (i.e., net uptake at a given P-loading rate gradually decreased over time; Small et al. 2008). The sustained positive net uptake rate suggests that substantial amounts of $\mathrm{P}$ were 
retained in the stream and either stored there long-term or transported out of the study reach as sediment or particulate organic matter.

This experiment was originally designed to isolate the effects of $\mathrm{P}$ on stream ecosystem processes. Other streams at La Selva receive inputs of groundwater high in $\mathrm{P}$ and other solutes $\left(\mathrm{Ca}^{2+}, \mathrm{Mg}^{2+}, \mathrm{Na}^{+}, \mathrm{K}^{+}, \mathrm{HCO}_{3}{ }^{-}, \mathrm{Cl}^{-}\right.$) (Pringle and Triska 1991). Stream ecosystem processes have been measured at the experimentally P-enriched Carapa and have been reported together with observations from the natural $\mathrm{P}$ gradient. The studies showed that P-enrichment in the Carapa stimulated microbial respiration, fungal biomass, leaf P-content, and leaf decomposition rates ( $\mathrm{Ra}$ mírez et al. 2003, 2006, Ardón et al. 2006, Stalcup et al. 2006, Ardón and Pringle 2007). The effects on higher trophic levels were less pronounced because P-enrichment did not stimulate higher growth rates of chironomid larvae (instead, chironomids feeding on high-P leaf litter showed elevated rates of $P$ excretion) (Small et al. 2011).

\section{Desorption}

For $2 \mathrm{~d}$ before $\mathrm{P}$ cutoff at the end of the 8-y P addition, $\mathrm{H}_{3} \mathrm{PO}_{4}$ inputs were switched from the gravity-fed carboy to a ceramic valveless metering pump (Fluid Metering Incorporated, Syosset, New York) to maintain a constant addition rate. Rhodamine WT (RhWT), a conservative tracer, was added simultaneously using a $2^{\text {nd }}$ metering pump during these $2 \mathrm{~d}$. Water samples were collected at 4-h intervals using ISCO 6712 samplers (Teledyne ISCO, Lincoln, Nebraska) deployed at stations 10, 50, and $100 \mathrm{~m}$ downstream from the injection site. After P and RhWT cutoff, which occurred at $1000 \mathrm{~h}$ local time on 23 February 2006, water samples were collected by hand at these stations, first at 1-min intervals, and then with decreasing frequency until $1400 \mathrm{~h}$. Samples were then collected every $4 \mathrm{~h}$ using ISCO samplers over a 48-h period. Water samples were analyzed at the station laboratory for SRP using the molybdenum blue method (APHA 1988) and RhWT using a benchtop fluorometer (model 10; Turner Designs, Sunnyvale, California).

Short-term P release from sediments after cutoff was estimated as the difference between observed and predicted SRP based on observed RhWT and the SRP:RhWT loading ratio (i.e., the SRP expected if it were to behave conservatively). The mass of $\mathrm{P}$ released from sediments passing out of the 50-m study reach in the first $48 \mathrm{~h}$ after P cutoff was estimated as the time integral of the excess $\mathrm{P}$ (difference between observed and predicted SRP curves) $\times$ discharge.

\section{Sediment $\mathbf{P}$ extractions}

Sediment $\mathrm{P}$ extractions were done $5 \mathrm{~d}$ before and after P cutoff (18 February 2006, 28 February 2006) at 5 stations along the study reach: $5 \mathrm{~m}$ upstream of the P injection (hereafter upstream), and 10, 50, 100, and $200 \mathrm{~m}$ downstream. Sediment present in the top $5 \mathrm{~cm}$ of the bed was collected with a small trowel and returned to the station laboratory. The bulk sample was gently homogenized with a spatula and passed through a $2-\mathrm{mm}$ sieve to remove large rocks and particulate matter. Most of the bulk sample passed through the sieve. Five replicate aliquots $(\sim 1$ g wet mass each) from each sieved sample were harvested for $\mathrm{P}$ extractions begun the following day. Sediment $\mathrm{P}$ was measured using a 5 -step sequential chemical fractionation procedure (D'Angelo 2005) that included, in sequence: 1) extraction with $20 \mathrm{~mL}$ of deionized water $(2 \mathrm{~h}), 2)$ extraction with $2 \mathrm{~mL}$ of $1 \mathrm{M} \mathrm{KCl}(2 \mathrm{~h}), 3)$ extraction with $20 \mathrm{~mL}$ of $0.1 \mathrm{M} \mathrm{NaOH}(24 \mathrm{~h})$, and 4) extraction with $20 \mathrm{~mL}$ of $0.5 \mathrm{M} \mathrm{HCl}$. The respective extracts yielded: 1) water-soluble inorganic and organic $P, 2$ ) weakly exchangeable inorganic and organic $\mathrm{P}, 3$ ) Fe- and Al-bound inorganic $\mathrm{P}$, and 4) organic fulvic- and humic-bound $\mathrm{P}$. Filtrates from each extraction were frozen and later analyzed for SRP as described above. Total P was measured on an acid-digested subsample of the filtrate (APHA 1988). Organic P was calculated as the difference between total and inorganic $\mathrm{P}$.

Sediment $\mathrm{P}$ extractions were repeated $\sim 1$ y later (5 March 2007) at the upstream and 10-m stations, focusing only on inorganic P (SRP) in filtrates of deionized water and $\mathrm{NaOH}$ extractions, based on the results of the original measurements that showed these to be the main components. Four years post-cutoff (12 April 2010), $\mathrm{NaOH}$ extractions were repeated at 4 stations along the study stream and at 7 nearby streams that ranged in SRP to provide additional context (Table 1 ).

\section{Sediment $\mathbf{P}$ adsorption isotherms}

In April 2010, following the return of sediment P concentrations to background levels, sediment $\mathrm{P}$ adsorption isotherms (Axt and Walbridge 1999) were generated for sediments collected from 4 stations along the Carapa study reach (upstream, and 10, 50, and $100 \mathrm{~m}$ downstream). Approximately $2 \mathrm{~g}$ sediment was equilibrated with solutions at 4 initial P concentrations: 936, 5330, 6727, and 15,950 $\mu \mathrm{g} / \mathrm{L}$. Incubations were done in triplicate and were allowed to equilibrate for $24 \mathrm{~h}$ on a shaker table. Samples were centrifuged, and the supernatant was analyzed for SRP as described above. The change in SRP relative to the initial concentration was used to calculate the mass of $\mathrm{P}$ adsorbed/g sediment dry mass.

\section{Biotic response}

To estimate the amount of $\mathrm{P}$ in the biotic compartments, epilithon, coarse particulate organic matter (CPOM), and macroinvertebrate samples were collected and analyzed for P content following methods described by Small and Pringle (2010). Epilithon was collected from unglazed ceramic tiles after 4-wk incubations at 4 stations (upstream, 10, 50, $100 \mathrm{~m}$ ) along the study stream. Tiles were 
Table 1. Mean (SE) sediment P content ( $\mu \mathrm{g}$ P/g dry sediment) for sediments collected from up to 5 different stations on the Carapa study stream on 4 different dates using 5 different extraction protocols. Also included are P extractions from 7 nearby streams that naturally vary in ambient soluble reactive P (SRP) concentrations because of inputs of geothermally modified ground water. Dates are formatted $\mathrm{mm} / \mathrm{dd} / \mathrm{yyyy}$. DI = deionized water.

\begin{tabular}{|c|c|c|c|c|c|c|c|}
\hline Stream & Date & $\begin{array}{l}\text { Ambient SRP } \\
(\mu \mathrm{g} \mathrm{P} / \mathrm{L})\end{array}$ & DI-extracted & $\begin{array}{c}\text { KCl-extracted } \\
\text { (undigested) }\end{array}$ & $\begin{array}{l}\text { KCl-extracted } \\
\text { (digested) }\end{array}$ & $\begin{array}{l}\mathrm{NaOH} \text {-extracted } \\
\text { (undigested) }\end{array}$ & $\begin{array}{c}\mathrm{NaOH} \text {-extracted } \\
\text { (digested) }\end{array}$ \\
\hline Carapa-up & $2 / 18 / 2006$ & 5 & $0.1(0)$ & $0.3(0.1)$ & $0.1(0)$ & $412.4(15.5)$ & $458(37.9)$ \\
\hline Carapa-10 & $2 / 18 / 2006$ & 850 & $0.7(0)$ & $0.3(0.1)$ & $0.2(0.1)$ & $698.8(18.2)$ & $709.5(47.6)$ \\
\hline Carapa-50 & $2 / 18 / 2006$ & 600 & $0.4(0.1)$ & $0.3(0)$ & & 391 (13.1) & $510.3(23.2)$ \\
\hline Carapa-100 & $2 / 18 / 2006$ & 400 & $2.9(1.5)$ & $0.2(0)$ & & $602.1(10.3)$ & $643.1(44.9)$ \\
\hline Carapa-200 & $2 / 18 / 2006$ & 300 & $1.6(1.4)$ & $0.3(0.1)$ & & 454.8 (19.4) & $346.6(39.1)$ \\
\hline Carapa-up & $2 / 28 / 2006$ & 5 & $0.6(0.1)$ & $0.1(0)$ & $0.1(0)$ & $339(2.7)$ & $406.9(23)$ \\
\hline Carapa-10 & $2 / 28 / 2006$ & 5 & $2(0)$ & $0.2(0)$ & 0.2 & $690.2(3.4)$ & $761.6(35.4)$ \\
\hline Carapa-50 & $2 / 28 / 2006$ & 5 & 2.6 & $0.1(0)$ & & $423.2(4.5)$ & $396.6(41.3)$ \\
\hline Carapa-100 & $2 / 28 / 2006$ & 5 & 1.9 & $0.2(0)$ & & 613.7 (7.6) & $580.3(75.7)$ \\
\hline Carapa-200 & $2 / 28 / 2006$ & 5 & $1.9(0.4)$ & $0.2(0)$ & & $411.5(4.3)$ & $434.8(39.5)$ \\
\hline Carapa-up & $3 / 5 / 2007$ & 5 & $0.2(0.1)$ & & & 176 (32.1) & \\
\hline Carapa-10 & $3 / 5 / 2007$ & 5 & $0.1(0)$ & & & $425.2(10.5)$ & \\
\hline Carapa-up & $4 / 12 / 2010$ & 5 & & & & $155.4(16.6)$ & \\
\hline Carapa-10 & $4 / 12 / 2010$ & 5 & & & & $126.3(13.2)$ & \\
\hline Carapa-50 & $4 / 12 / 2010$ & 5 & & & & 131.7 (13.3) & \\
\hline Carapa-100 & $4 / 12 / 2010$ & 5 & & & & 129 (10.9) & \\
\hline Piper-30 & $3 / 5 / 2007$ & 2 & 0.1 & & & $20.7(7.2)$ & \\
\hline Sura-60 & $3 / 5 / 2007$ & 3 & 0 & & & $90.9(17.1)$ & \\
\hline Saltito-100 & $3 / 5 / 2007$ & 3 & $0.1(0)$ & & & $234.3(12.8)$ & \\
\hline Taconazo-30 & $3 / 5 / 2007$ & 3 & $0.4(0)$ & & & 406.7 (70.3) & \\
\hline Salto-60 & $3 / 5 / 2007$ & 10 & $0.4(0.3)$ & & & $300.8(106.2)$ & \\
\hline Sura-30 & $3 / 5 / 2007$ & 83 & $0.6(0.1)$ & & & 783.6 (33.8) & \\
\hline Arboleda-30 & $3 / 5 / 2007$ & 135 & $0.2(0)$ & & & $459.4(130.7)$ & \\
\hline
\end{tabular}

collected at 1-mo intervals, immediately before P cutoff and for the subsequent 4 mo. Epilithon was scrubbed from tiles, filtered onto a $0.45-\mu \mathrm{m}$ glass-fiber filter, and dried. Grab samples of CPOM and macroinvertebrates were collected at these 4 stations on 2 dates prior to P cutoff and on 6 dates over the ensuing 4 months. Biotic samples were dried at $50^{\circ} \mathrm{C}$ for $48 \mathrm{~h}$, acid-digested (Aqua Regia double acid; Jones et al. 1991), and analyzed spectrophotometrically (ascorbic acid method). Ground pine needles (US National Institute of Standards and Technology, 1575a) were used as an external standard.

On one date before cutoff (19 January 2006) and 2 dates after cutoff (8 March 2006 and 30 June 2006), microbial respiration rates on leaf disks were measured with methods described by Ramírez et al. (2003). Leaves of Ficus insipida, a common riparian plant species in Central America, were used as a standardized substrate. Groups of Ficus leaves were incubated in the stream for $14 \mathrm{~d}$ at stations 10, 50, 100, 200, and $500 \mathrm{~m}$ below the site of P addition. Disks were cut from these leaves and incubated at ambient tem- perature in a chamber with a stirrer and $\mathrm{O}_{2}$ probe. Rates were expressed as $\mathrm{O}_{2}$ consumed by microbes per gram ashfree dry mass (AFDM) per hour ( $\mathrm{mg} \mathrm{O}_{2} \mathrm{~g}^{-1}$ AFDM h$\left.^{-1}\right)$. The $P$ content of the remaining material was measured as described above.

\section{$P$ budget}

Storage of dissolved $\mathrm{P}$ in the water column within the 50- $\mathrm{m}$ study reach during the P-addition experiment was calculated as the mean SRP concentration from the final $48 \mathrm{~h}$ of $\mathrm{P}$ addition, multiplied by the reach volume, where stream width and depth were estimated as $1.0 \mathrm{~m}$ and $0.1 \mathrm{~m}$, respectively. The background level was based on postexperiment sampling over the ensuing months. Groundwater seepage flux $(\sim 3.5 \mu \mathrm{g} \mathrm{P} / \mathrm{s})$ was considered to be negligible relative to the stream P flux $(>1000 \mu \mathrm{g} \mathrm{P} / \mathrm{s})$. The half-life of dissolved $\mathrm{P}$ in this reach was calculated from the decline in SRP measured at the 50-m downstream station after $P$ cutoff. 
Areal P concentrations were estimated for the sediment P fractions by applying bulk density of sediments sampled for $\mathrm{P}$ extractions and assuming a $5-\mathrm{cm}$ active layer of sediment. Background sediment P storage was based on the 2010 measurements. The half-life of P stored in sediment was calculated by fitting an exponential decay curve to the time-series data.

For $\mathrm{P}$ storage in epilithon, the biomass on the ceramic tiles $(15 \times 7.7 \mathrm{~cm})$ was conservatively extrapolated throughout the wetted stream channel, and epilithon biomass was assumed to be constant over time (i.e., changes in estimated $P$ storage were caused by changing $P$ content of epilithon). The background level was based on the final measurement, and the half-life was calculated by fitting an exponential decay curve to the time-series data.

Biomass of CPOM was estimated from quarterly samples collected with a stovepipe corer during and after the 8 -y experiment. The areal density of organic matter in these samples did not change significantly, so the mean was used and applied to CPOM \%P measurements to calculate CPOM $\mathrm{P}$ storage. Background CPOM P storage was based on the final CPOM \%P measurement, and the half-life was calculated by fitting an exponential decay curve to the timeseries data.
Insect biomass was based on biomass measurements for chironomid larvae reported in Ramírez and Pringle (2006), and chironomid \%P values were taken from Small et al. (2011). Chironomids dominate invertebrate biomass in headwater streams at La Selva and have higher P content than other insect taxa in the stream, so the extent of underestimating the size of the insect $\mathrm{P}$ pool caused by excluding other taxa is relatively small. Fish biomass and $\mathrm{P}$ content from the study stream were reported by Small et al. (2012).

\section{RESULTS}

Desorption

During the final days of $\mathrm{P}$ addition, SRP concentrations averaged 819,549 , and $365 \mu \mathrm{g} / \mathrm{L}$ at the 10-, 50- and 100-m stations, respectively (Fig. 1A, B). Based on RhWT concentrations, discharge averaged $1.71,2.43$, and $3.12 \mathrm{~L} / \mathrm{s}$ at the 10-, 50- and 100-m stations, respectively. Based on mass balance, $\mathrm{P}$ uptake averaged $9.5 \mathrm{mg} \mathrm{P} \mathrm{m}^{-2} \mathrm{~h}^{-1}$ between 10 and $50 \mathrm{~m}$ downstream, and $11.5 \mathrm{mg} \mathrm{P} \mathrm{m}^{-2} \mathrm{~h}^{-1}$ between 50 and $100 \mathrm{~m}$ downstream during the $48 \mathrm{~h}$ before $\mathrm{P}$ cutoff.

$\mathrm{P}$ concentrations returned to background levels over the $48 \mathrm{~h}$ after $\mathrm{P}$ cutoff (Fig. 1A, B). P released from sedi-

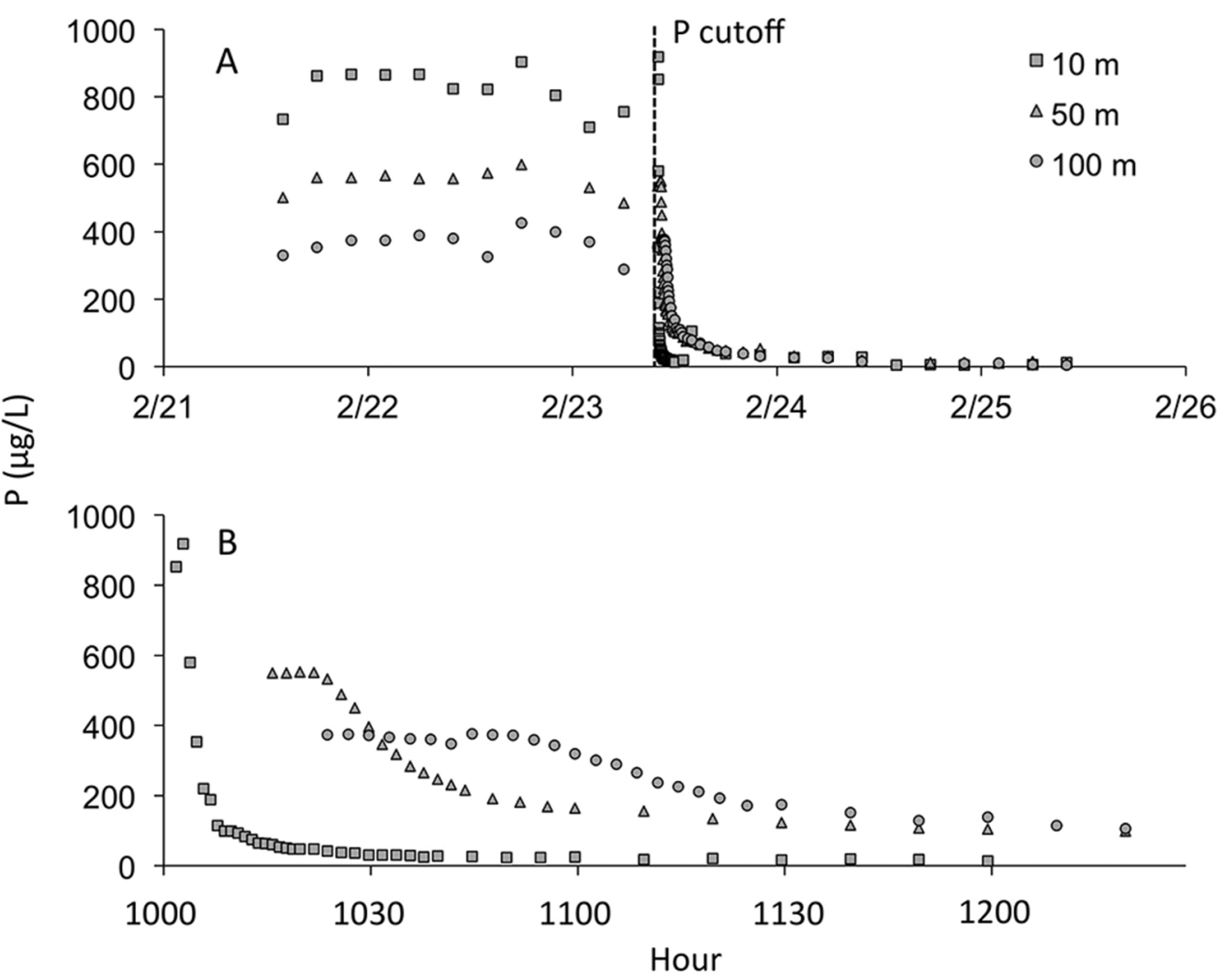

Figure 1. Soluble reactive P (SRP) concentrations at stations 10, 50, and $100 \mathrm{~m}$ downstream of the injection site during a 96-h period around the P cutoff in 2006 (A) and details for the 2-h period after the cutoff (B). 
ments resulted in SRP concentrations up to $80 \mu \mathrm{g} / \mathrm{L}$ above background initially at the 50- and 100-m stations, tapering off over the ensuing $48 \mathrm{~h}$ (Fig. 2). These data suggest P release of $\sim 150 \mathrm{mg} / \mathrm{m}^{2}$ in the first $2 \mathrm{~d}$ at a rate of $\sim 3 \mathrm{mg}$ $\mathrm{P} \mathrm{m}^{-2} \mathrm{~h}^{-1}$.

\section{Sediment $\mathbf{P}$ extractions}

$\mathrm{NaOH}$ extractions yielded $\mathrm{P}$ concentrations $\sim 4$ orders of magnitude higher than $\mathrm{DI}$ and $\mathrm{KCl}$ extractions (Table 1), indicating that nearly all stored $\mathrm{P}$ was $\mathrm{Al}$ - or Febound. No consistent longitudinal pattern was found in sediment P levels 10, 50, 100, and $200 \mathrm{~m}$ downstream of the $\mathrm{P}$ injection in the Carapa (Table 1). However, a plot of the P levels at the 10-m station vs time shows a clear temporal pattern for $\mathrm{P}$ levels in the reach (Fig. 3). At the end of the injection, the average $\mathrm{NaOH}$-extractable $\mathrm{P}$ was similar to $\mathrm{NaOH}$-extractable $\mathrm{P}$ measured in nearby naturally high-P streams. After $1 \mathrm{y}$, sediment $\mathrm{P}$ at the Carapa $10-\mathrm{m}$ station had declined by $38 \%$, and after 4 y had declined by $82 \%$ to a level similar to nearby naturally low-P streams. The station $5 \mathrm{~m}$ upstream of the injection site was intended to be a control because it was separated by a riffle from the point of $P$ injection, but elevated SRP levels were observed at this station throughout the experiment, and sediment at this station showed a corresponding $2.3 \times$ enrichment in P levels.

\section{Sediment $\mathbf{P}$ adsorption isoclines}

Sediment $\mathrm{P}$ isoclines indicated that Carapa sediments had the capacity to retain $\sim 50$ to $100 \mu \mathrm{g} \mathrm{P} / \mathrm{g}$ dry sediment at background SRP levels of $100 \mu \mathrm{g} / \mathrm{L}$, and 150 to $250 \mu \mathrm{g}$ $\mathrm{P} / \mathrm{g}$ dry sediment at background SRP levels of $1000 \mu \mathrm{g} / \mathrm{L}$ (Fig. 4). Sediments collected from the upstream stations (above the injection site and $10 \mathrm{~m}$ below) had a higher sorption capacity than sediments collected at the 50- and 100-m stations.

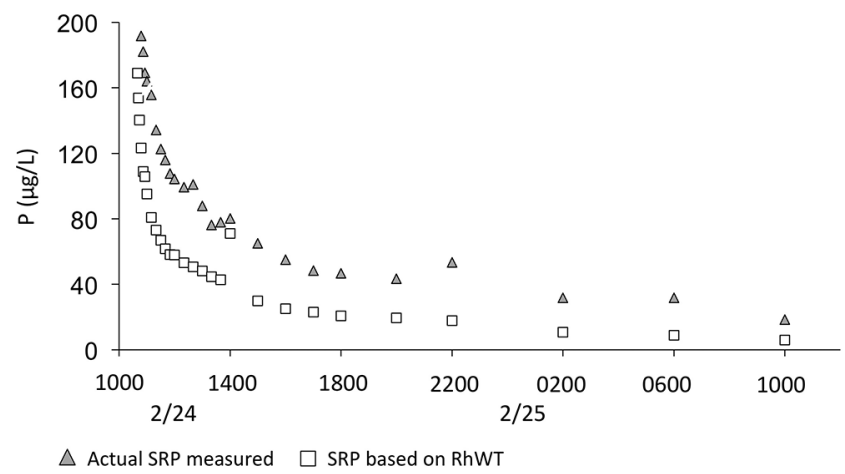

Figure 2. Soluble reactive P (SRP) and calculated SRP (based on Rhodamine WT [RhWT] and SRP:RhWT input ratio) at the 50 - $\mathrm{m}$ station over a 48-h period after P cutoff in 2006. Difference between the curves was used to estimate short-term $\mathrm{P}$ release from sediment.

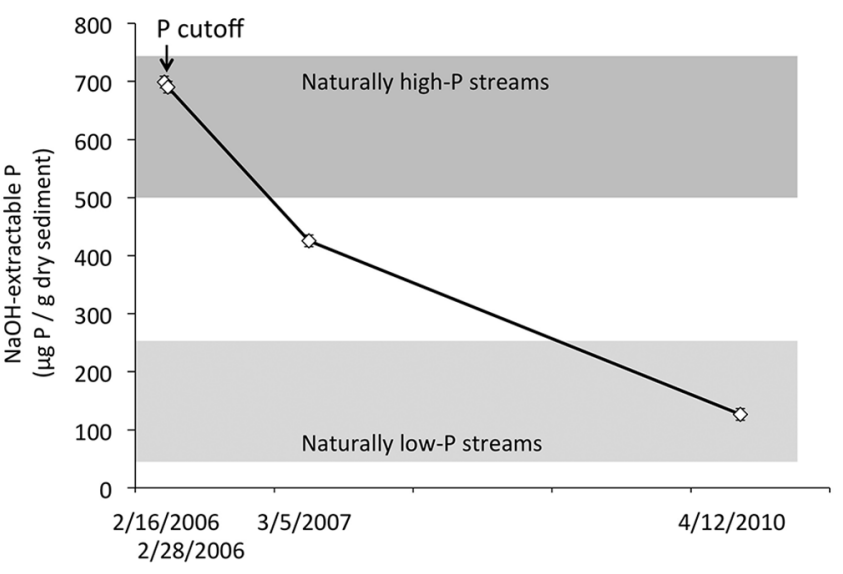

Figure 3. Mean $( \pm 1 \mathrm{SE}) \mathrm{NaOH}$-extractable $\mathrm{P}$ from sediment at $10-\mathrm{m}$ station shortly before (16 February 2006) and after (28 February 2006) P-cutoff and $\sim 1$ (5 March 2007) and 4 y (12 April 2010) after cutoff. Shaded regions indicate the range of $\mathrm{NaOH}$-extractable $\mathrm{P}$ measured from nearby naturally highand low-P streams.

\section{Biotic response}

Epilithon P content was initially $0.2-0.3 \%$ by dry mass, in the lower range of values measured on tiles in nearby naturally high-P streams (Fig. 5). Epilithon \%P declined to $0.1 \% 4$ mo after P cutoff. Leaf litter $\% \mathrm{P}$ was $\sim 0.10 \%$ before $\mathrm{P}$ cutoff, lower than values in naturally high-P streams, and gradually returned to background levels of $\sim 0.06 \%$ over the next 4 mo (Fig. 6). P content of Ficus leaf packs incubated in the stream declined after $\mathrm{P}$ cutoff that was similar to the decline in P content of CPOM grab samples. Both $\mathrm{P}$ content and microbial respiration rates on the Ficus

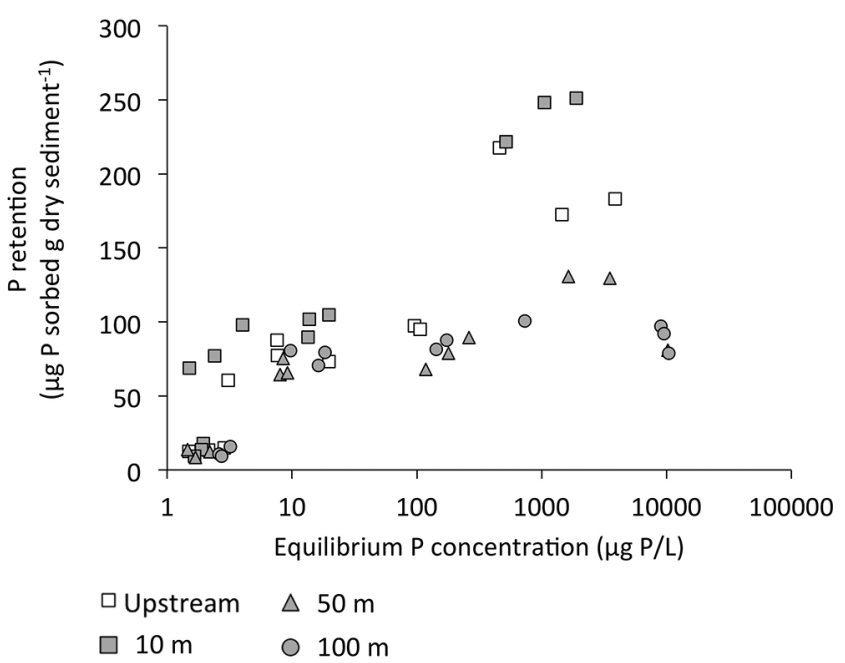

Figure 4. P sorption isoclines for sediment collected from 4 stations. Measurements were done $4 \mathrm{y}$ after the P cutoff and sediment $\mathrm{P}$ content had returned to baseline levels. 


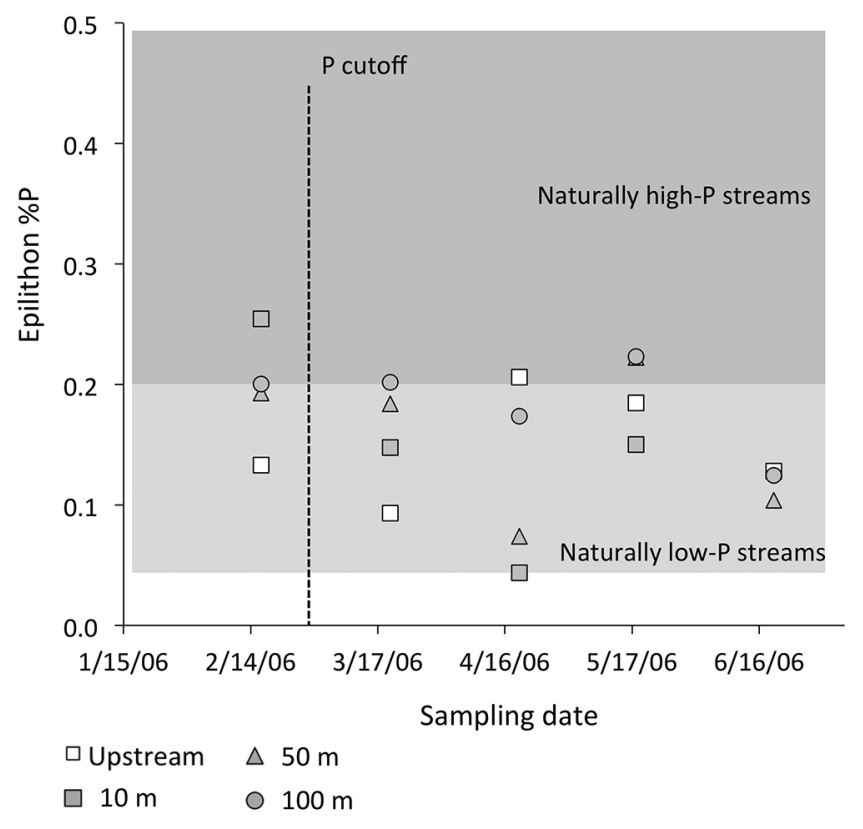

Figure 5. P content of epilithon collected from ceramic tiles at 4 stations in the study stream over 5 sampling dates in 2006 after P cutoff. Shaded regions depict epilithon P content from naturally high- and low-P streams in the region (Small and Pringle 2010).

leaves were $\sim 3 \times$ higher before the cutoff than 4 mo after cutoff (Figs 6, 7).

\section{$P$ budget}

During the P-addition experiment, water showed the greatest relative increase, $\sim 36 \times$ background levels, with a half-life of $0.1 \mathrm{~d}$ (Table 2). Fe- and Al-bound sediment $\mathrm{P}$ was by far the greatest P reservoir, accounting for $99 \%$ of stored $\mathrm{P}$ in the stream ecosystem, with an estimated $88,000 \mathrm{mg} \mathrm{P} / \mathrm{m}^{2}$ at the end of $\mathrm{P}$ addition, compared to an estimated $15,800 \mathrm{mg} \mathrm{P} / \mathrm{m}^{2}$ background at this site (a $5.5 \times$ increase). This large sediment $\mathrm{P}$ pool also had the longest half-life of any measured compartment at $235 \mathrm{~d}$. Based on these numbers, at the time of $\mathrm{P}$ cutoff, the 200-m reach below the P-addition point contained $\sim 13 \mathrm{~kg} \mathrm{P}$ above background levels, nearly $25 \%$ of the total P added $(53.8 \mathrm{~kg})$ over the 8-y study. In comparison, P storage in biotic compartments was negligible. We estimated $\sim 11 \mathrm{mg}$ excess $\mathrm{P} / \mathrm{m}^{2}$ stored in epilithon and $\sim 7 \mathrm{mg}$ excess $\mathrm{P} / \mathrm{m}^{2}$ stored in CPOM (Table 2). These biotic compartments had relatively long half-lives (epilithon: $63 \mathrm{~d}$, CPOM: $91 \mathrm{~d}$ ). No increase in $\mathrm{P}$ content was observed in insects in the study reach.

\section{DISCUSSION}

After 8 y of nearly constant P loading designed to simulate conditions in nearby naturally high-P streams, we found that sediment, but not biotic compartments, reached
P levels comparable to those measured in naturally high-P streams. More than $99 \%$ of excess $P$ in the study reach was stored as Al- and Fe-bound sediment P, accounting for $10 \%$ of the total $\mathrm{P}$ added over the $8-\mathrm{y}$ experiment. This finding is consistent with observed patterns of sustained $P$ uptake based on longitudinal SRP measurements throughout the 8-y experiment (Small et al. 2008).

The observed dynamics of $P$ release from sediments after the end of the enrichment-an initial pulse followed by a sustained slow release-is consistent with the 2-step kinetic model described by Froelich (1988). The sorption of SRP onto precipitated $\mathrm{Al}$ or Fe hydroxides is relatively slow and occurs over hundreds of hours (Bolan et al. 1985). In streams where suspended sediment concentrations are low, diffusion of SRP into the sediments becomes a rate-limiting step (House et al. 1995). The P stored on the interior of particles would have been relatively resistant to short-timescale fluctuations in SRP concentration that occurred during the experiment, and the P stored on the exterior of particles would have acted to stabilize SRP concentrations over the course of the experiment.

In contrast to sediment, biotic compartments showed a low level of $\mathrm{P}$ enrichment and were a negligible contributor to reach-scale P storage. Detritus (CPOM) and epilithon were enriched 1.7 and $3.1 \times$, respectively, but these levels represented $<1 / 2$ the $\mathrm{P}$ content of detritus and epilithon in a nearby naturally high-P stream (Small and Pringle 2010). The reason for this muted response is not entirely clear, given the relatively high SRP concentrations

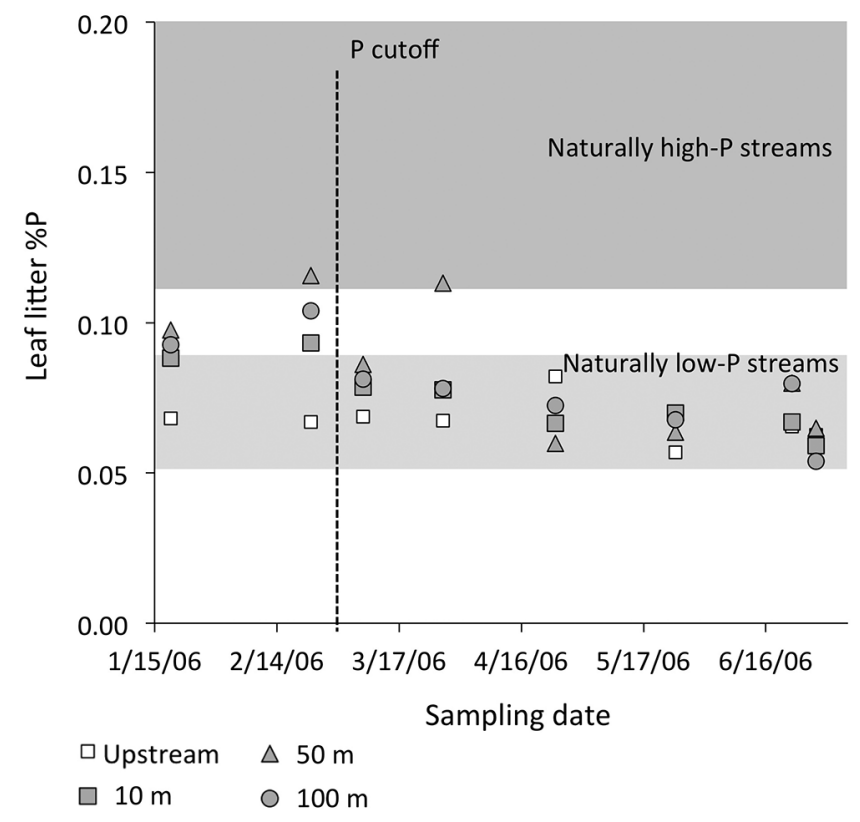

Figure 6. P content of Ficus leaves incubated in stream water at 4 stations in the study stream over 5 sampling dates in 2006 after P cutoff. Shaded regions depict Ficus leaf P content from incubations in naturally high- and low-P streams (Small et al. 2011). 


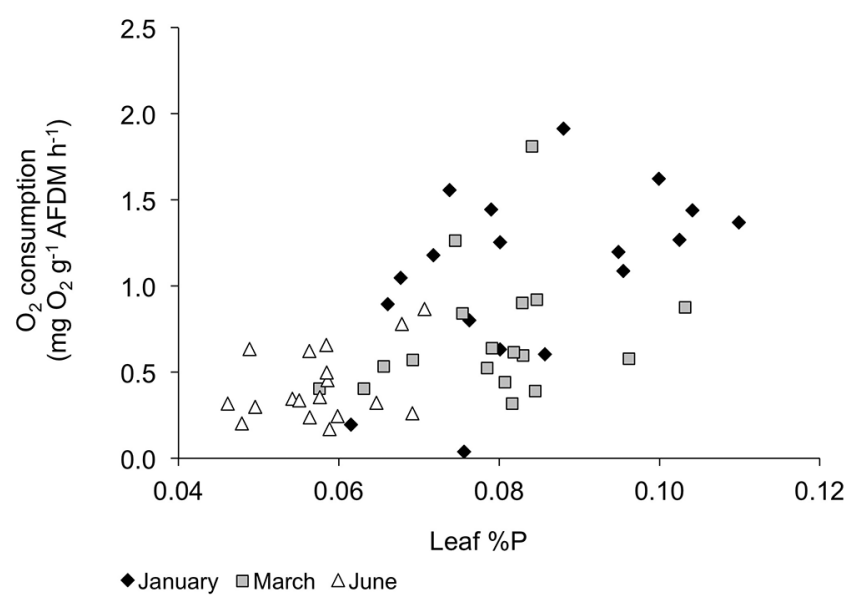

Figure 7. Ficus leaf-disk $\mathrm{O}_{2}$ consumption rates vs leaf $\mathrm{P}$ content during $\mathrm{P}$ addition (January 2007) and after P cutoff (March and June 2007). AFDM = ash-free dry mass.

documented at the downstream stations throughout the experiment (Small et al. 2008) and the long turnover time of $\mathrm{P}$ in these biotic compartments (Table 2) relative to fluctuations in $\mathrm{P}$ inputs during the experiment. One factor that may have suppressed biotic $P$ storage in the study reach was the downstream transport of materials. Throughout the experiment, sediment and leaf litter were transported into the study reach laterally and from upstream of the injection site, effectively diluting the pool of P-enriched substrate. Likewise, an unknown but potentially significant amount of P probably was exported from the study reach in the form of suspended organic matter and sediments. The half-life values estimated in Table 2 represent a combination of actual P removal from substrate (via desorption, mineralization, etc.) with the turnover of substrate resulting from new inputs and downstream transport. The fact that saturation of net $\mathrm{P}$ uptake was observed over the course of the experiment (Small et al. 2008) suggests that the time scale of $\mathrm{P}$ retention is faster than the time scale of sediment turnover. It seems possible that turnover of organic material caused by downstream transport out of the study reach may have occurred faster relative to time scales of P retention (e.g., Cushing et al. 1993).

The most pronounced biotic response to P addition was microbial respiration, a result illustrating the important linkage between $\mathrm{P}$ and $\mathrm{C}$ dynamics in this detritus-based stream. These results were consistent with respiration rates reported in the Carapa early in the P-enrichment experiment and from nearby streams that naturally range in $\mathrm{P}$ (Ramírez et al. 2003). Our results expand on the results of a study by Ramírez et al. (2003) by showing the relationship between leaf $\mathrm{P}$ and respiration rates and documenting the return to baseline conditions over a 4-mo period (Fig. 7). A $3 \times$ increase in microbial respiration rates could have potentially large implications for turnover rates of organic $\mathrm{C}$. However, changes in the standing stock of detritus were not observed over the course of our study, suggesting that other factors, such as consumption by invertebrates and downstream transport, may be more important. Nutrient additions in a detritus-based headwater stream in the southeastern USA also resulted in elevated microbial respiration rates (Benstead et al. 2009). Benstead et al. (2009) also documented an even larger response in the export of fine particulate organic matter (FPOM), mediated by shifts in the invertebrate community (Davis et al. 2010). We did not measure export of FPOM in the Carapa, but the lack of observed response by either detritus or insect standing stocks in our study may indicate that invertebrates played a limited role in mediating the ecosystem response to $\mathrm{P}$ addition. In contrast to the southeastern USA stream, in which nutrient enrichment led to increased production of primary consumers (Davis et al. 2010), the dominant invertebrate consumers in the Carapa, chironomid larvae,

Table 2. Estimated P budget at the end of the 8-y P-addition experiment compared to background levels. The lower value for watersoluble sediment $\mathrm{P}\left(86 \mathrm{mg} \mathrm{P} / \mathrm{m}^{2}\right)$ came from P extractions in deionized water. The higher value $\left(150 \mathrm{mg} \mathrm{P} / \mathrm{m}^{2}\right)$ was calculated by measuring excess soluble reactive P (SRP) relative to the conservative tracer at the end of the experiment (Fig. 2). Half-life values were calculated by fitting an exponential decay model to time-series measurements after the end of the $\mathrm{P}$ addition. $\mathrm{CPOM}=$ coarse particulate organic matter.

\begin{tabular}{llcccc}
\hline Category & Description & Enrichment $\left(\mathrm{mg} \mathrm{P} / \mathrm{m}^{2}\right)$ & Background $\left(\mathrm{mg} \mathrm{P} / \mathrm{m}^{2}\right)$ & Relative increase & Half-life $(\mathrm{d})$ \\
\hline Dissolved & Water & 73 & 2 & 36 & 0.1 \\
Sediment & Water soluble & $86-300$ & 18 & $5-17$ & 0.5 \\
Sediment & Fe- and Al-bound & 88,000 & 15,800 & 5.5 & 235 \\
Sediment & Organic fulvic and humic-bound & 1340 & 17 & 6 & 3.1 \\
Biotic & Epilithon & 17 & 10 & 1.7 & 0 \\
Biotic & CPOM & 1 & 1 & 0 & 91 \\
Biotic & Insects & 15 & 15 & 0 & \\
Biotic & Fish & 17 & & \\
\hline
\end{tabular}


were not able to respond to P-enriched food with increased growth rates or $\mathrm{P}$ storage, but instead excreted the additional P they consumed (Small et al. 2011), indicating that these consumers were adapted to low-P food resources.

Our results reflect the response of a single stream to $\mathrm{P}$ addition, and whether the patterns of $\mathrm{P}$ retention observed here would apply to streams in other regions is not clear. The clay-rich soils and acidic streams of La Selva Biological Station probably provide conditions that are favorable for sediment P retention (Fig. 4), and the dense forest canopy precluded a strong algal response to nutrient addition. P exported from our study reach into higherorder streams with increased light availability could have led to increased algal production there. Studies in several other rivers have documented patterns in P retention similar to what we observed. For example, sediments in a $3^{\text {rd }}$ order stream in the southeastern USA buffered stream SRP concentrations against variable SRP loading from an upstream wastewater treatment plant (Haggard et al. 2005). In the UK, sediments in river basins receiving sewage effluent discharges consistently acted as SRP sinks, whereas sediments in other river basins acted as SRP sources (Jarvie et al. 2005). Reductions in point-source P loading in the River Lambourn led to an abrupt shift from net uptake to net release of $\mathrm{P}$ from sediments for the subsequent 9 mo (Jarvie et al. 2006). Legacy P in terrestrial soils, floodplains, and lake sediments can persist on time scales from decades to centuries (Sharpley et al. 2014), but the time scale of recovery for our study reach is consistent with other reported values for in-channel P storage (Owens et al. 2001, Jarvie et al. 2006, Collins and Walling 2007a, b, Ballantine et al. 2009).

$\mathrm{P}$ is of central importance in the management of aquatic ecosystems. Thus, improved understanding is needed of the relationships among $\mathrm{P}$ loading, availability, and the capacity for $\mathrm{P}$ storage in stream ecosystems. These relationships control ecological responses to P loading in streams and the magnitude and timing of $\mathrm{P}$ exported downstream. In future nutrient-addition experiments (e.g., experiments associated with the Stream Experimental Observatory Network), researchers should take advantage of opportunities to follow the fate of $\mathrm{P}$ added to streams, in addition to measuring biotic responses that result from this P. Such measurements will allow us to better understand how stream ecosystems respond to, and recover from, P loading.

\section{ACKNOWLEDGEMENTS}

We are grateful to Minor Hidalgo for maintaining the 8-y P-addition experiment and to Ronald Avanzino for help with chemical analyses. This study was supported by the National Science Foundation through the Long-Term Studies in Environmental Biology program (DEB 9528434, DEB 0075339, DEB 0545463). We thank Jennifer McGuire for constructive comments on an early version of this manuscript.

\section{LITERATURE CITED}

Aldridge, K. T., J. D. Brookes, and G. G. Ganf. 2010. Changes in abiotic and biotic phosphorus uptake across a gradient of stream condition. River Research and Applications 26:636-649.

APHA (American Public Health Association). 1988. Standard methods for the examination of water and wastewater. $20^{\text {th }}$ edition). American Public Health Association, American Water Works Association, and Water Environment Federation, Washington, DC.

Ardón, M. A., and C. M. Pringle. 2007. Organic matter quality mediates heterotrophic biofilm response to phosphorus enrichment of the water column and substratum. Freshwater Biology 52:1762-1772.

Ardón, M. A., L. Stallcup, and C. M. Pringle. 2006. Does leaf quality mediate the stimulation of leaf breakdown by phosphorus in Neotropical streams? Freshwater Biology 51:618633.

Axt, J. R., and M. R. Walbridge. 1999. Phosphate removal capacity of palustrine forested wetlands and adjacent uplands in Virginia. Soil Science Society of America Journal 63:1019-1031.

Ballantine, D. J., D. E. Walling, A. L. Collins, and G. J. L. Leeks. 2009. The content and storage of phosphorus in fine-grained channel bed sediments in contrasting lowland agricultural catchments in the UK. Geoderma 151:141-149.

Bennett, E. M., S. R. Carpenter, and N. F. Caraco. 2001. Human impact on erodable phosphorus and eutrophication: a global perspective. BioScience 51:227-234.

Benstead, J. P., A. D. Rosemond, W. F. Cross, J. B. Wallace, S. L. Eggert, K. Suberkropp, V. Gulis, J. L. Greenwood, and C. J. Tant. 2009. Nutrient enrichment alters storage and fluxes of detritus in a headwater stream ecosystem. Ecology 90:25562566.

Bolan, N. S., N. J. Barrow, and A. M. Posner. 1985. Describing the effect of time on sorption of phosphate by iron and aluminium hydroxides. Journal of Soil Science 36:187-197.

Bukaveckas, P. A. 2007. Effects of channel restoration on water velocity, transient storage, and nutrient uptake in a channelized stream. Environmental Science and Technology 41:15701576.

Carpenter, S. R., and E. M. Bennett. 2011. Reconsideration of the planetary boundary for phosphorus. Environmental Research Letters 6:014009.

Chen, Y. S. R., J. N. Butler, and W. Stumm. 1973. Kinetic study of phosphate reaction with aluminum oxide and kaolinite. Environmental Science and Technology 7:327-332.

Collins, A. L., and D. E. Walling. 2007a. Fine-grained bed sediment storage within the main channel systems of the Frome and Piddle catchments, Dorset UK. Hydrological Processes 21:1448-1459.

Collins, A. L., and D. E. Walling. 2007b. The storage and provenance of fine sediment on the channel bed of two contrasting lowland permeable catchments, UK. River Research and Applications 23:429-450.

Cushing, C. E., G. W. Minshall, and J. D. Newbold. 1993. Transport dynamics of fine particulate organic matter in two Idaho streams. Limnology and Oceanography 38:1101-1115.

D’Angelo, E. M. 2005. Phosphorus sorption capacity and exchange by soils from mitigated and late successional bottomland forest wetlands. Wetlands 25:297-305. 
Davis, J. M., A. D. Rosemond, S. L. Eggert, W. F. Cross, and J. B. Wallace. 2010. Long-term nutrient enrichment decouples predator and prey production. Proceedings of the National Academy of Sciences of the United States of America 107:121126.

Dorioz, J. M., E. Pilleboue, and A. Ferhi. 1989. Phosphorus dynamics in watersheds: role of trapping processes in sediments. Water Research 23:147-158.

Drake, W. M., J. T. Scott, M. Evans-White, B. Haggard, A. Sharpley, and C. W. Rogers. 2012. The effect of periphyton stoichiometry and light on biological phosphorus immobilization and release in streams. Limnology 13:97-106.

Elser, J. J., M. E. S. Bracken, E. E. Cleland, D. S. Gruner, W. S. Harpole, H. Hillebrand, J. T. Ngai, E. W. Seabloom, J. B. Shurin, and J. E. Smith. 2007. Global analysis of nitrogen and phosphorus limitation of primary producers in freshwater, marine and terrestrial ecosystems. Ecology Letters 10:11351142.

Elwood, J. W., J. D. Newbold, R. V. O'Neill, R. W. Stark, and P. T. Singley. 1981. The role of microbes associated with organic and inorganic substrates in phosphorus spiralling in a woodland stream. Verhandlungen der Internationalen Vereinigung für theoretische und angewandte Limnologie 21:850-856.

Froelich, P. N. 1988. Kinetic control of dissolved phosphate in natural rivers and estuaries: a primer on the phosphate buffer mechanism. Limnology and Oceanography 33:659-668.

Frossard, E., M. Brossard, M. J. Hedley, and A. Metherell. 1995. Reactions controlling the cycling of P in soils. Pages 107-137 in H. Tiessen (editor). Phosphorus in the global environment: transfers, cycles and management. John Wiley and Sons, New York.

Haggard, B. E., E. H. Stanley, and D. E. Storm. 2005. Nutrient retention in a point-source-enriched stream. Journal of the North American Benthological Society 24:29-47.

House, W. A., and F. H. Denison. 1998. Phosphorus dynamics in a lowland river. Water Research 32:1819-1830.

House, W. A., and F. H. Denison. 2000. Factors influencing the measurement of equilibrium phosphate concentrations in river sediments. Water Research 34:1187-1200.

House, W. A., and F. H. Denison. 2002. Exchange of inorganic phosphate between river waters and bed-sediments. Environmental Science and Technology 36:4295-4301.

House, W. A., F. H. Denison, J. T. Smith, and P. D. Armitage. 1995. An investigation of the effects of water velocity on inorganic phosphorus influx to a sediment. Environmental Pollution 89:263-271.

Jarvie, H. P., M. D. Jürgens, R. J. Williams, C. Neal, J. J. L. Davies, C. Barrett, and J. White. 2005. Role of river bed sediments as sources and sinks of phosphorus across two major eutrophic UK river basins: the Hampshire Avon and Herefordshire Wye. Journal of Hydrology 304:51-74.

Jarvie, H. P., C. Neal, M. D. Juergens, E. J. Sutton, M. Neal, and H. D. Wickham. 2006. Within-river nutrient processing in chalk streams: the Pang and Lambourn, United Kingdom. Journal of Hydrology 330:101-125.

Jones, J. B., B. Wolf, and H. A. Mills. 1991. Plant analysis handbook. Micro-Macro, Athens, Georgia.

Kleber, M., L. Schwendenmann, E. Veldkamp, J. Rössner, and R. Jahn. 2007. Halloysite versus gibbsite: silicon cycling as a ped- ogenetic process in two lowland Neotropical rain forest soils of La Selva, Costa Rica. Geoderma 138:1-11.

Meyer, J. M. 1979. The role of sediments and bryophytes in phosphorus dynamics in a headwater stream ecosystem. Limnology and Oceanography 24:365-375.

Mulholland, P. J., E. R. Marzolf, J. R. Webster, D. R. Hart, and S. P. Hendricks. 1997. Evidence that hyporheic zones increase heterotrophic metabolism and phosphorus uptake in forest streams. Limnology and Oceanography 42:443-451.

Newbold, J. D., J. W. Elwood, R. V. O'Neill, and A. L. Sheldon. 1983. Phosphorus dynamics in a woodland stream ecosystem: a study of nutrient spiralling. Ecology 64:1249-1265.

Owens, P. N., D. E. Walling, J. Carton, A. A. Meharg, J. Wright, and G. J. L. Leeks. 2001. Downstream changes in the transport and storage of sediment-associated contaminants $(\mathrm{P}, \mathrm{Cr}$, and PCBs) in agricultural and industrialized drainage basins. Science of the Total Environment 266:177-186.

Peterson, B. J., J. E. Hobbie, A. E. Hershey, M. A. Lock, T. E. Ford, J. R. Vestal, V. L. McKinley, M. A. J. Hullar, M. C. Miller, R. M. Ventullo, and G. S. Volk. 1985. Transformation of a tundra river from heterotrophy to autotrophy by addition of phosphorus. Science 27:1383-1386.

Pringle, C. M., and F. J. Triska. 1991. Effects of geothermal groundwater on nutrient dynamics of a lowland Costa Rican stream. Ecology 72:951-965.

Pringle, C. M., F. J. Triska, and G. J. Browder. 1990. Spatial variation in basic chemistry of streams draining a volcanic landscape on Costa Rica's Caribbean slope. Hydrobiologia 206:7386.

Ramírez, A., and C. M. Pringle. 2006. Fast growth and turnover of chironomid assemblages in response to stream phosphorus levels in a tropical lowland landscape. Limnology and Oceanography 51:189-196.

Ramírez, A., C. M. Pringle, and M. Douglas. 2006. Temporal and spatial patterns in stream physicochemistry and insect assemblages in tropical lowland streams. Journal of the North American Benthological Society 25:108-123.

Ramírez, A., C. M. Pringle, and L. Molina. 2003. Effects of stream phosphorus levels on microbial respiration. Freshwater Biology 48:88-97.

Reddy, K. R., R. H. Kadlec, E. Flaig, and P. M. Gale. 1999. Phosphorus retention in streams and wetlands: a review. Critical Reviews in Environmental Science and Technology 29:83146.

Schade, J. D., K. MacNeill, S. A. Thomas, F. C. McNeely, J. R. Welter, and J. Hood. 2011. The stoichiometry of nitrogen and phosphorus spiraling in heterotrophic and autotrophic streams. Freshwater Biology 56:424-436.

Schindler, D. W. 1977. Evolution of phosphorus limitation in lakes. Science 195:260-262.

Sharpley, A., H. P. Jarvie, A. Buda, L. May, B. Spears, and P. Kleinman. 2014. Phosphorus legacy: overcoming the effects of past management practices to mitigate future water quality impairment. Journal of Environmental Quality 42:13081326.

Slavik, K., B. J. Peterson, L. A. Deegan, W. B. Bowden, A. E. Hershey, and J. E. Hobbie. 2004. Long-term responses of the Kuparuk River ecosystem to phosphorus fertilization. Ecology 85:939-954. 
Small, G. E., M. Ardón, A. P. Jackman, H. H. Duff, F. J. Triska, A. Ramírez, M. Snyder, and C. M. Pringle. 2012. Rainfalldriven amplification of seasonal acidification in poorly buffered tropical streams. Ecosystems 15:974-985.

Small, G. E., A. M. Helton, and C. Kazanci. 2009. Can consumer stoichiometric regulation control nutrient spiraling in streams? Journal of the North American Benthological Society 28:747765.

Small, G. E., and C. M. Pringle. 2010. Deviation from strict homeostasis across multiple trophic levels in an invertebrate consumer assemblage exposed to high chronic phosphorus enrichment in a Neotropical stream. Oecologia (Berlin) 162: 581-590.

Small, G. E., C. M. Pringle, F. J. Triska, J. H. Duff, A. P. Jackman, M. Hidalgo, A. Ramírez, and M. Ardon. 2008. The dynamics of phosphorus retention during an eight-year P-addition in a Neotropical headwater stream. Verhandlungen der Internationalen Vereinigung für theoretische und angewandte Limnologie 30:551-554.

Small, G. E., P. J. Torres, L. M. Schweizer, J. H. Duff, and C. M. Pringle. 2013. Importance of terrestrial arthropods as subsi- dies in lowland Neotropical rain forest stream ecosystems. Biotropica 45:80-87.

Small, G. E., J. P. Wares, and C. M. Pringle. 2011. Differences in phosphorus demand among detritivorous chironomid larvae reflect intraspecific adaptations to differences in food resource stoichiometry across lowland tropical streams. Limnology and Oceanography 56:268-278.

Sollins, P., M. F. Sancho, C. R. Mata, and R. L. Sanford. 1994. Soils and soil process research. Pages 9-13 in L. A. McDade, K. S. Bawa, H. A. Hespenheide, and G. S. Hartshorne (editors). La Selva: ecology and natural history of a Neotropical rainforest. University of Chicago Press, Chicago, Illinois.

Stalcup, L. A., M. Ardón, and C. M. Pringle. 2006. Does nitrogen become limiting under high-P conditions in detritus-based tropical streams? Freshwater Biology 51:1515-1526.

Stream Solute Workshop. 1990. Concepts and methods for assessing solute dynamics in stream ecosystems. Journal of the North American Benthological Society 9:95-119.

Vanni, M. J., G. Boros, and P. B. McIntyre. 2013. When are fish sources vs. sinks of nutrients in lake ecosystems? Ecology 94: 2195-2206. 